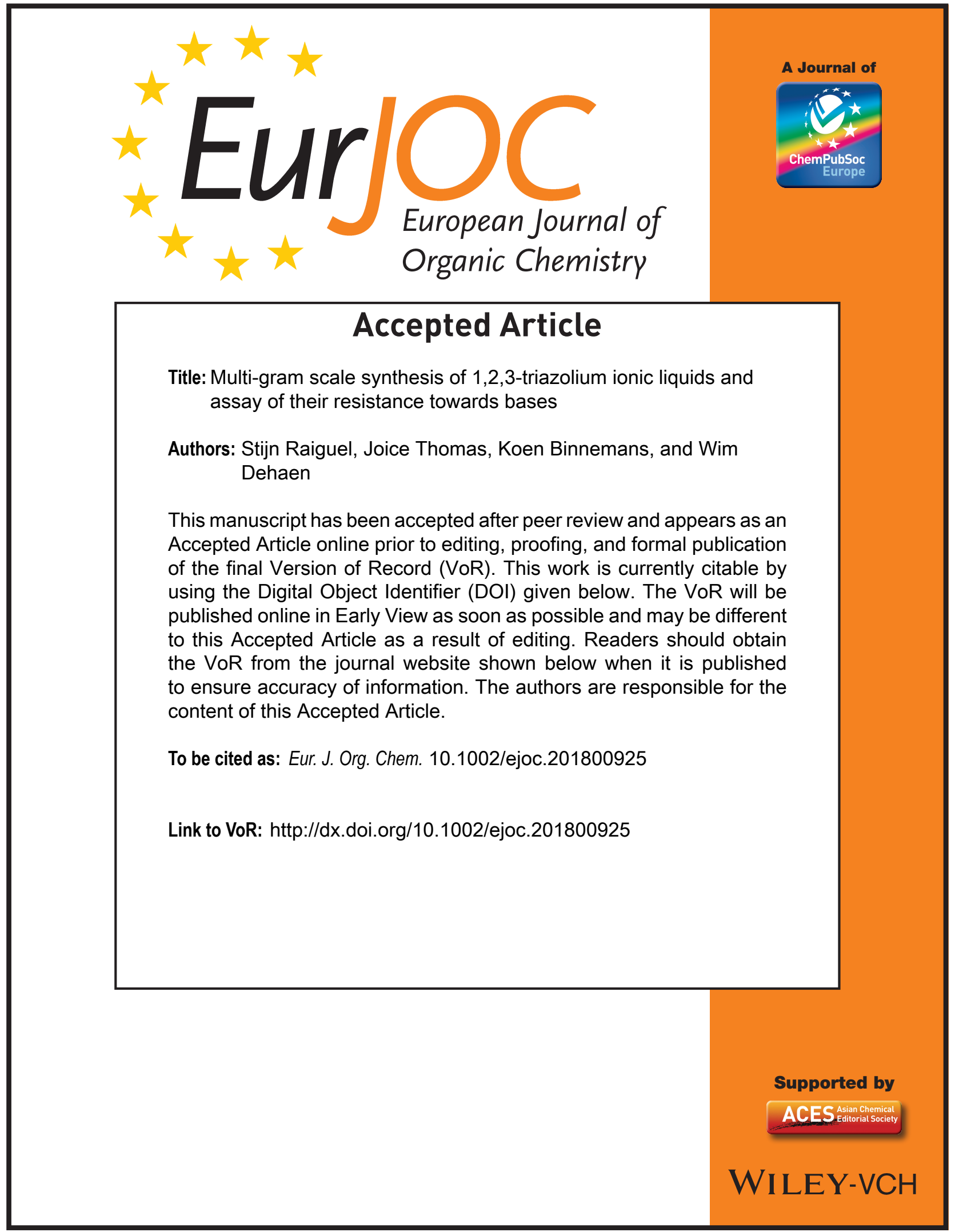




\section{Multi-gram scale synthesis of 1,2,3-triazolium ionic liquids and assay of their resistance towards bases}

\begin{abstract}
An easily upscalable synthesis method for 1,2,3-triazolium ionic liquids is presented. Several ionic liquids were synthesized and characterized. The influence of the side chain structure on the basestability was investigated. One example, functionalized with linear alkyl side chains, was found to exhibit excellent stability against hot concentrated $\mathrm{NaOH}$ solutions and Grignard reagents.
\end{abstract}

Stijn Raiguel, ${ }^{[a]}$ Joice Thomas, ${ }^{[a]}$ Koen Binnemans ${ }^{[a]}$ and Wim Dehaen ${ }^{*[a]}$

\section{Introduction}

Ionic liquids are generally solvents with wide electrochemical windows, making them resistant to oxidation and reduction. ${ }^{[1,2]}$ However, the cations of most ionic liquids are susceptible to attack by strong Brønsted bases, precluding their use in combination with strong alkalis and rendering them poor solvents for reactions involving organometallic reagents. Quaternary ammonium ionic liquids degrade via a $\beta$-elimination reaction known as the Hofmann elimination, affording an alkene and the corresponding amine. ${ }^{[3-5]}$ Phosphonium ionic liquids, while structurally analogous to quaternary ammonium ionic liquids, decompose through an entirely different mechanism, involving the attack of hydroxide ions at the phosphorus center, eventually forming a phosphine oxide and an alkane. ${ }^{[4,6]} 1,3$ Dialkylimidazolium ionic liquids are by far the most base-sensitive of all commonly used classes of ionic liquids. ${ }^{[3]}$ Inductive effects of the nitrogen atoms flanking the C2-position strongly polarize this methine moiety, rendering it sufficiently acidic for quantitative deprotonation by bases as weak as $\mathrm{Cs}_{2} \mathrm{CO}_{3}{ }^{[7]}$ The resulting product is a reactive but neutral $\mathrm{N}$-heterocyclic carbene, so that the ionic character of the solvent is lost. ${ }^{[3]}$

Several researchers have attempted to improve the basestability of ionic liquids, often compromising upon their physical properties, such as melting point or viscosity. Alkylation of the C2position of imidazolium ionic liquids limits deprotonation at this site thereby improving their usability in alkaline conditions. . $3,8-10]^{2}$ However, this position remains susceptible to nucleophilic attack and proton exchange even after substitution. ${ }^{[3,8,11,12]}$ Hugar et al. reported that the only way to entirely eliminate the reactivity of this position is to functionalize this position with a 2,6-dimethylphenyl group, which results in high melting points. ${ }^{[8]} A$ similar strategy of steric shielding can be employed for ammonium and phosphonium ionic liquids. Ionic liquids based on the bis(2ethylhexyl)dimethylammonium cation have shown excellent stability in $50 \mathrm{wt} \% \mathrm{NaOH}$. However, the resulting ionic liquids are all very viscous and water-soluble, making them rather unsuited

[a] S. Raiguel, J. Thomas, K. Binnemans and W. Dehaen Department of Chemistry KU Leuven

Celestijnenlaan 200F P.O. Box 2404, B-3001 Leuven, Belgium E-mail:wim.dehaen@kuleuven.be

Supporting information for this article is given via a link at the end of the document. as reaction media and extractants. ${ }^{[5]}$ For similar reasons, longchain phosphonium ionic liquids are also compatible with strong bases without the formation of phosphine oxides. ${ }^{[13]}$ However, they suffer from increased viscosities and lower loading capacities in solvent extraction, due to the large volume of the cation. ${ }^{[13-17]}$ In addition, conflicting reports do exist, as some authors report observing the a-deprotonation of long-chain phosphonium ionic liquids, resulting in the formation of a nonionic phosphorane. ${ }^{[3,18]}$

The lesser-known 1,2,3-triazolium ionic liquids do not behave like imidazolium ionic liquids when combined with bases, as a result of the nitrogen atom present at their 2-position. ${ }^{[19,20]}$ Deprotonation or addition at this position are no longer significant pathways of degradation. However, Hofmann elimination could potentially occur, a pathway which is not observed in the alkaline decomposition of imidazolium ionic liquids. ${ }^{[8,21]}$ To investigate the dependence of the stability towards bases on the nature of the side chain, we have synthesized peralkylated 1,2,3-triazolium ionic liquids with linear and branched alkyl chains located on the $\mathrm{N} 1$ - and N3-positions. As reported by Lethesh and coworkers, branching at the $\beta$-position is effective at sterically inhibiting Hofmann elimination, should this process occur. ${ }^{[5]}$

Earlier literature on 1,2,3-triazolium salts has mainly focused on trisubstituted triazolium salts. ${ }^{[20,22-26]}$ Liquid 1,2,3triazolium salts have been used as solvents for the BaylisHilmann, Michael, aldol and Vilsmeyer-Haack reactions, as chiral reaction media, as electrolytes in dye-sensitized photovoltaics and as extractants for metal ions. ${ }^{[21,23,27-30]}$ Previous studies have also reported on liquid crystalline phases and the effect of side chain branching in 1,2,3-triazolium ionic liquids. ${ }^{[31,32]}$ Outside the field of ionic liquids, these salts have been used as organocatalysts, as precursors to mesionic carbene ligands and as structural units in anion-selective probes. ${ }^{[23]}$ While 1,2,3triazolium ionic liquids are relatively novel, the 1,2,3-triazole platform has been popularized in other fields. ${ }^{[33-38]}$ This is largely a result of the copper- and ruthenium-catalyzed azide-alkyne click reactions, which provide very convenient pathways towards 1,4and 1,5-disubstituted 1,2,3-triazoles, respectively. ${ }^{[39,40]}$ While very effective for certain applications, the reaction has several notable drawbacks. Primarily, both azides and alkynes are uncommon reagents with limited commercial availability. In addition, only terminal alkynes tend to be sufficiently reactive to afford high yields of the desired product in the copper-catalyzed variant of the method. ${ }^{[39]}$ The ruthenium-catalyzed click reaction is compatible with internal alkynes, but the high cost of the catalyst, sensitivity to steric hindrance and variable regiochemistry render this variant less attractive. ${ }^{[40,41]}$ The toxicity of the metal catalysts is a further disadvantage, which is especially pertinent in medicinal chemistry. In this paper, we present a new method for the synthesis of 1,2,3-triazolium ionic liquids with high resistance towards bases. This pathway is inspired by a method described by Thomas and Dehaen in 2016, which affords trisubstituted 1,2,3-triazoles from primary amines and ketones via an enamine intermediate. ${ }^{[42,43]}$ The procedure is metal-free and requires the synthesis of only 
one common organic azide, regardless of the compound of interest. This compound can thus be synthesized in bulk, while all other reagents can be obtained commercially at relatively low cost. In our adjusted method, 4-nitrophenyl azide is replaced by 4azidobenzoic acid. The carboxylic acid group serves the same activating function as the nitro group does in the original method, but its acidity allows for convenient removal of the spent azide by extraction with an alkaline aqueous solution. The method further makes use of the basicity of the amine and the volatility of most simple ketones to facilitate the purification of the final product. Highly pure, peralkylated 1,2,3-triazoles can thus be obtained in larger quantities without the need of using column chromatography for purification, making this method ideal for the synthesis of triazole-derived ionic liquids. Up to $30 \mathrm{~g}$ of starting azide could be used without compromising upon the yield of the procedure (see synthesis of 4-ethyl-1,3-bis(2-ethylhexyl)-5methyl-1,2,3-triazolium nitrate).

$$
\text { ineat or DMF }
$$

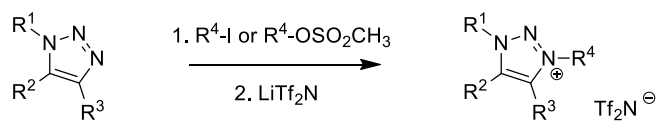

Scheme 1. General reaction scheme for the synthesis of 1,2,3-triazolium ionic liquids.

\section{Results and Discussion}

The reaction conditions used in the method described by Thomas et al. were adapted and optimized for the new reagent combination. Parameters retained from the original procedure were the stoichiometric excess of amine (1.4 eq.) and the use of $4.0 \AA$ molecular sieves to promote the formation of the intermediate enamine. 4-Azidobenzoic acid is in general less soluble than the nitro-substituted analog, requiring a change in solvent conditions. Initially, test reactions were performed in acetonitrile with 3-pentanone, 2-ethylhexylamine and isobutylamine as model substrates. The obtained yields were modest: $44 \%$ and $23 \%$ for the 2-ethylhexyl and isobutyl products, respectively. All reaction mixtures were turbid due to the poor solubility of 4-azidobenzoic acid or its ammonium salts in acetonitrile. Increasing the excess of 3-pentanone and performing the reaction under solvent-free conditions led to a reduction of the turbidity of most reaction mixtures, with some even becoming fully homogeneous. This increase in solubility of the azide led to correspondingly higher yields. Furthermore, the elimination of the nitrile solvent increases the 'green' character of this synthetic procedure. ${ }^{[4]}$ High molecular weight amines were observed to afford better yields under identical conditions than amines with low molecular weights. However, due to the lower cost of low molecular weight amines, this can be counteracted by the addition

of a larger excess of the amine. Presumably, the poor solubility of the azidobenzoate salts of these amines reduces their availability to react with the ketone, which is the rate-determining step in the mechanism of the triazolation described by Dehaen and coworkers. ${ }^{[42]}$ This strategy was effective for isobutylamine and other lower amines (Figure 1). For heavier, poorly-soluble amines, dimethylformamide provided an excellent reaction medium.

Benzylamine yielded two regioisomers, 4-methyl-5-ethyland 4-ethyl-5-methyl-substituted 1-benzyltriazole, as baseinduced cleavage of the 1,3-dibenzyltriazolium-4-ethyl-5-methyl cation afforded a product mixture displaying identical resonances in its ${ }^{1} \mathrm{H}$ NMR spectrum. The formation of these two regioisomers was observed in both acetonitrile and solvent-free conditions. The formation of only one product was described by Thomas et al. when similar substrates were used. ${ }^{[42]}$ Based on their observations, the 4-methyl-5-ethyl derivative is expected to be formed selectively. The ratio of both products changed from 45:55 to $92: 8$ in favor of the expected regioisomer in solvent-free conditions. ${ }^{[42]}$ Treating the 92:8 mixture with aminobenzoic acid in acetonitrile at $80^{\circ} \mathrm{C}$ did not cause a change in the isomer ratio, implying that the observed 1,3-'shift' occurs during the formation of the product, and is not an acid-catalyzed rearrangement of the final product.

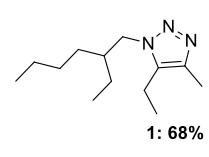<smiles>CCCCc1c(C)nnn1CC(C)C</smiles><smiles>CCCCCCc1c(C)nnn1CC(C)(C)C</smiles>

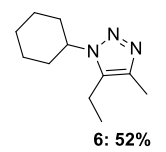
6: $52 \%$
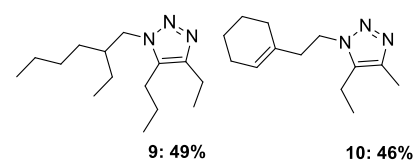<smiles>CCCCc1c(C)nnn1CCCC</smiles><smiles>CCCCCCCc1c(C)nnn1CCCCCC</smiles><smiles>[R]c1nnn(Cc2ccccc2)c1[R]</smiles>
$7 a+7 b: 46 \%, 10: 1$ 7a: $R^{1}=E t, R^{2}=M e$ $7 \mathrm{~b}: \mathrm{R}^{1}=\mathrm{Me}, \mathrm{R}^{2}=\mathrm{Et}$

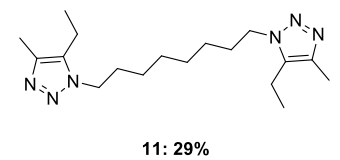

Figure 1. Scope with respect to 1,2,3-triazoles that are useful as ionic liquid precursors. The given percentages indicate the obtained yields. Reaction conditions: 1.4 eq. amine, solvent-free for $1,4,5,7,9,10$; 3.0 eq. amine, solvent free for $2,3,8 ; 1.4$ eq. amine, DMF for $6 ; 0.5$ eq. amine, DMF for 11.

As shown in Figure 1, various useful precursors to peralkylated 1,2,3-triazolium ionic liquids can be obtained in good to fair yields. Unfortunately, the high acidity of the reaction medium renders this procedure ineffective if derivatives obtained from highly reactive ketones (e.g. acetone or cyclohexanone) are targeted. Acid-sensitive functional groups (e.g. alcohols or acetals) are also poorly tolerated. Regardless, this is of little concern when applying this method to the synthesis of ionic liquid precursors, as mostly aliphatic, linear side chains are required in order to obtain desirable physical properties (low melting point and low viscosity).

1,2,3-Triazoles were found to be readily quaternized by alkyl methanesulfonates. lodoalkanes react as well, albeit much more 
Table 1. Physicochemical properties of the synthesized ionic liquids.

\begin{tabular}{|c|c|c|c|c|c|}
\hline & {$[\mathrm{EhEhT}]\left[\mathrm{Tf}_{2} \mathrm{~N}\right]$} & ['Bu'BuT][Tf $2 \mathrm{~N}]$ & {$\left[\mathrm{Eh}^{\mathrm{i}} \operatorname{PrT}\right]\left[\mathrm{Tf}_{2} \mathrm{~N}\right]$} & {$[\mathrm{HHT}]\left[\mathrm{Tf}_{2} \mathrm{~N}\right]$} & {$[\mathrm{EhEhT}]\left[\mathrm{NO}_{3}\right]$} \\
\hline Dynamic viscosity, dry, $30^{\circ} \mathrm{C}(\mathrm{mPa} \cdot \mathrm{s})$ & 276 & 4600 & 210 & 67 & 4581 \\
\hline Density, dry, $20^{\circ} \mathrm{C}\left(\mathrm{g} \cdot \mathrm{cm}^{-3}\right)$ & 1.20 & 1.35 & 1.26 & 1.24 & 1.02 \\
\hline Residual water after drying (ppm) & 4850 & 1700 & 3600 & 1480 & $1.55 w t \%$ \\
\hline Water content at saturation (wt\%) & 1.52 & 5.89 & 2.30 & 0.51 & 30.3 \\
\hline $\begin{array}{l}\text { Dynamic viscosity, water saturated, } 30^{\circ} \mathrm{C} \\
\qquad(\mathrm{mPa} \cdot \mathrm{s})\end{array}$ & 207 & 293 & 135 & 54 & 30 \\
\hline Decomposition temperature ${ }^{[\mathrm{a}]}\left({ }^{\circ} \mathrm{C}\right)$ & 305 & 308 & 290 & 333 & 220 \\
\hline Solubility in water (ppm) & 74 & 1218 & 614 & 45 & $7.2 \mathrm{wt} \%$ \\
\hline
\end{tabular}

All products are liquid at room temperature. a Given as onset point. Temperature scan rate $3^{\circ} \mathrm{C} \cdot \min ^{-1}$. Procedure shown in supporting information, page S2.

slowly. The resultant methanesulfonate (mesylate) ionic liquids are water-soluble, even with hydrophobic cations, and can thus be easily purified and subsequently converted to bis(trifluoromethylsulfonyl)imide (bistriflimide) ionic liquids. We used this method to prepare five ionic liquids with varying degrees of branching (Figure 2). These ionic liquids were then characterized and their resistance against strong bases was evaluated by recording the ${ }^{1} \mathrm{H}$ NMR of base-contacted ionic liquids. The results of these assays are shown in Tables 1 and 2.

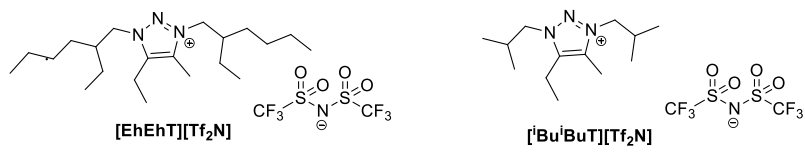

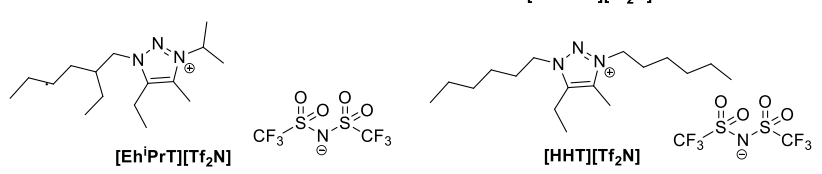

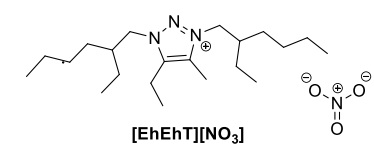

Figure 2. Structures of the synthesized 1,2,3-triazolium ionic liquids

The physical properties largely follow the same trends as observed for other classes of ionic liquids. Due to the increase in energy barrier for side chain rotation, branching increases the viscosity of ionic liquids. ${ }^{[45]}$ The highest hydrophobicity (lowest water solubility) was observed for the ionic liquids with the most hydrophobic side chains. The high viscosity of ['Bu'BuT] $\left[\mathrm{Tf}_{2} \mathrm{~N}\right]$ could be attributed to its compact cation undergoing strong electrostatic interactions. One ionic liquid with a nitrate anion was prepared, which features a lower degree of charge delocalization. As a result, this ionic liquid is more viscous and more hydrophilic than its bis(trifluoromethylsulfonyl)imide analog. These typical physical properties contrast with the chemical properties of the ionic liquids, which are quite unlike those observed for quaternary ammonium ionic liquids. Most notably, $[\mathrm{HHT}]\left[\mathrm{Tf}_{2} \mathrm{~N}\right]$ displays excellent resistance to both concentrated $\mathrm{NaOH}$ at elevated temperatures and Grignard reagents, although it is decomposed by $n$-butyllithium. The branched ionic liquids [EhEhT][Tf $\left.{ }_{2} \mathrm{~N}\right]$ and [EhiPrT][Tf $\left.{ }_{2} \mathrm{~N}\right]$ are more easily attacked by bases. Decomposition of $\left[\right.$ EhiPrT] $\left[\mathrm{Tf}_{2} \mathrm{~N}\right]$ by $\mathrm{NaOH}$ selectively gives 5-ethyl-1-(2ethylhexyl)-4-methyltriazole as decomposition product, which is in agreement with a Hofmann elimination occurring at the sensitive isopropyl side chain. However, the stability of the $n$-hexyl side chain and the sensitivity of the 2-ethylhexyl side chains in $[\mathrm{HHT}]\left[\mathrm{Tf}_{2} \mathrm{~N}\right]$ and $[\mathrm{EhEhT}]\left[\mathrm{Tf}_{2} \mathrm{~N}\right]$ cannot be explained by a simple E2 decomposition mechanism. This differs from what is observed for quaternary ammonium ionic liquids. ${ }^{[3-5]}$ Furthermore, only the side chain adjacent to the methyl group appears susceptible to elimination in [EhEhT] $\left[\mathrm{Tf}_{2} \mathrm{~N}\right.$ ], selectively yielding the precursor triazole and 2-ethylhexanol as decomposition products. Ethylmagnesium bromide affects [EhEhT] $\left[\mathrm{Tf}_{2} \mathrm{~N}\right]$ and $[\mathrm{HHT}]\left[\mathrm{Tf}_{2} \mathrm{~N}\right]$ in more or less the same manner as concentrated $\mathrm{NaOH}$ does. $\mathrm{A}$ different behavior is observed for [ $\left[\mathrm{Eh}^{\mathrm{i}} \mathrm{PrT}\right]\left[\mathrm{Tf}_{2} \mathrm{~N}\right]$, which appears to form two decomposition products when treated with a Grignard base, with the parent triazole being the minority product. This also disagrees with a Hofmann-type mechanism.

Deuterium isotope exchange studies were conducted on [EhEhT][Tf $\left.{ }_{2} \mathrm{~N}\right]$ and $[\mathrm{HHT}]\left[\mathrm{Tf}_{2} \mathrm{~N}\right]$ to gain more insight into the possible pathway of degradation. After $3 \mathrm{~h}$ at $80{ }^{\circ} \mathrm{C}$ in $40 \mathrm{wt} \%$ $\mathrm{NaOD}$ in $\mathrm{D}_{2} \mathrm{O}$, the degree isotope exchange was $49 \%$ and $51 \%$,

Table 2. Stability assay of the synthesized ionic liquids.

\begin{tabular}{|c|c|c|c|c|c|}
\hline & {$[E h E h T]\left[\mathrm{Tf}_{2} \mathrm{~N}\right]$} & ['Bu'BuT][Tf $\left.{ }_{2} \mathrm{~N}\right]$ & {$\left[E h^{i} \operatorname{PrT}\right]\left[\mathrm{Tf}_{2} \mathrm{~N}\right]$} & {$[\mathrm{HHT}]\left[\mathrm{Tf}_{2} \mathrm{~N}\right]$} & {$[\mathrm{EhEhT}]\left[\mathrm{NO}_{3}\right]$} \\
\hline \multicolumn{6}{|c|}{ mol\% remaining after contact with: } \\
\hline $50 \mathrm{wt} \% \mathrm{NaOH}, 60^{\circ} \mathrm{C}, 24 \mathrm{~h}$ & 97 & n.d. ${ }^{a}$ & 91 & 100 & 95 \\
\hline$n$-BuLi, RT, 90 min & 0 & $90-100$ & n.d. & 0 & n.d. \\
\hline
\end{tabular}

a Not determined, pathway of degradation is dissimilar to that of other ionic liquids. ${ }^{\text {b}}$ Anionic decomposition occurs. 
respectively, occurring selectively on the C4-methyl groups. This suggests a possible involvement of the C4-methyl group in the decomposition mechanism, possibly due to an intramolecular rearrangement involving an attack on the adjacent side chain, explaining the occurrence of only one decomposition product.

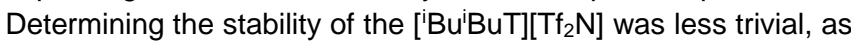
the precursor triazole does not appear to be a decomposition product of this ionic liquid. Alkaline attack occurs most readily by $\mathrm{NaOH}$ and appears to take place on the core ring structure itself, resembling the decomposition pathway of imidazoles. ${ }^{[8]}$ For this reason, it was not possible to determine the exact degree of decomposition of this ionic liquid in concentrated $\mathrm{NaOH}$. The structural integrity of this cation was better conserved in the presence of the organometallic bases ethylmagnesium bromide and $n$-butyllithium. While some other minor, poorly defined signals appear in the ${ }^{1} \mathrm{H}$ NMR spectra after treating [ $\left.{ }^{[} \mathrm{Bu}^{i} \mathrm{BuT}\right]\left[\mathrm{Tf}_{2} \mathrm{~N}\right]$ with organometallic bases, no major pathways of decomposition could be discerned. These bases may be sterically hindered from attacking in a similar fashion to the more compact hydroxide anion, kinetically protecting the ionic liquid under harsh conditions.

The nitrate analog of $[E h E h T]\left[\mathrm{Tf}_{2} \mathrm{~N}\right], \quad[\mathrm{EhEhT}]\left[\mathrm{NO}_{3}\right]$, demonstrates similar stability with respect to concentrated $\mathrm{NaOH}$ as the bistriflimide ionic liquid. However, signals corresponding to an alkene and two isomeric triazoles are detected by ${ }^{1} \mathrm{H}$ NMR, indicating that $\beta$-elimination is the main pathway of decomposition for the more hydrophilic nitrate ionic liquid. This possibly results from the high water content of this ionic liquid, allowing hydroxide anions to diffuse into the ionic liquid phase more effectively and attacking the cation directly, rather than deprotonating the cation at the interface. The most striking difference in behavior of the nitrate ionic liquid is observed when contacting it with ethylmagnesium bromide in tetrahydrofuran. Whilst the degree of cationic decomposition was very limited, a symmetric product yielding an $\mathrm{ABX}_{3}$ spectrum on ${ }^{1} \mathrm{H}$ NMR was observed to have formed. We hypothesize this is a product of the reduction of the nitrate anion by the Grignard reagent, similar to the product which are observed when nitro compounds are treated by Grignard reagents. ${ }^{[46]}$ COSY and HSQC spectra for this compound are provided in the supporting information.

The feasibility of Grignard reactions in $[\mathrm{HHT}]\left[\mathrm{Tf}_{2} \mathrm{~N}\right]$ was investigated. lodobutane was metalated with magnesium in $[\mathrm{HHT}]\left[\mathrm{Tf}_{2} \mathrm{~N}\right]$ and subsequently treated with benzaldehyde. While an acid-soluble precipitate did develop upon quenching with water acidifying and extracting with heptane did not however afford any product other than the starting benzaldehyde. Law et al. reported that iodide Grignard reagents could be generated in $\mathrm{N}$ butylpyridinium tetrafluoroborate, but readily convert to aggregate organomagnesium species, which do not undergo typical Grignard reactions either. ${ }^{[4]}$ Adding a Lewis basic cosolvent regenerates the free Grignard reagent and allows one to perform Grignard reactions in ionic liquid media. ${ }^{[4-49]}$ As proof of concept, we report without optimization that the expected Grignard addition product was observed when a solution of $n$-dodecylmagnesium bromide in diethyl ether was added to a solution of $n$-pentanal in $[\mathrm{HHT}]\left[\mathrm{Tf}_{2} \mathrm{~N}\right]$, similar to what is reported by Law et al., who used pyridine as cosolvent for their pyridinium ionic liquid. It should be noted that Grignard reagents can add to pyridinium salts. ${ }^{[50]}$ We did not observe any decomposition or reduction of $[\mathrm{HHT}]\left[\mathrm{Tf}_{2} \mathrm{~N}\right]$ under Grignard reaction conditions and therefore propose this ionic liquid as a more robust medium for Grignard reactions.

\section{Conclusions}

In conclusion, several new 1,2,3-triazolium ionic liquids were synthesized using a new method that is easily upscalable. Up to $30 \mathrm{~g}$ of starting azide was used without a significant reduction in yield. The described products cannot be obtained via CuAACbased methods as the copper-catalyzed triazole synthesis is incompatible with internal alkynes. Advantages of this method over RuAAC-based methods are the absence of the costly catalyst, the lower cost and risks associated with the starting materials and the fixed regiochemistry. The influence of the side chain structure on the stability of 1,2,3-triazolium ionic liquids in basic media was studied. Linear side chains afford the highest stability against concentrated $\mathrm{NaOH}$ and Grignard reagents. When decomposition does occur, it appears to proceed via a previously unreported mechanism, in which linear side chains display lower rates of decomposition than branched side chains. However, both the degree of decomposition and the mechanism through which it occurs are strongly dependent on the nature of the cation and the anion of the ionic liquid being studied. These ionic liquids show promise as media for several organic reactions in which strongly basic reagents are required.

\section{Experimental Section}

General synthesis of 1,2,3-triazolium ionic liquids: The ketone (12 eq.) amine (1.4 eq.) and azide (1.0 eq.) reagents are combined and stirred at $80^{\circ} \mathrm{C}$ for $16-20 \mathrm{~h}$ with $4 \AA$ molecular sieves. After the reaction, excess starting materials are evaporated and the reaction mixture is suspended in toluene and filtered. The filtrate is washed three times with $10 \mathrm{wt} \%$ $\mathrm{NaH}_{2} \mathrm{PO}_{4}$ and three times with $1 \mathrm{M} \mathrm{NH}_{3}$ mixed with 20 vol\% brine. The organic phase is dried over $\mathrm{MgSO}_{4}$ and concentrated under vacuum to afford the 1,2,3-triazole. Alkyl mesylate (1.1 eq.) is added to the 1,2,3triazole. The resulting mixture is stirred at $80-100^{\circ} \mathrm{C}$ for $2-3 \mathrm{~d}$. The reaction mixture is dissolved in water and washed 3 times with heptane. A lithium bis(trifluoromethylsulfonyl)imide solution is added, upon which the ionic liquid forms a second phase. A 50/50 volume ratio mixture of heptane and ethyl acetate is added to dissolve the ionic liquid phase, which is then washed with lithium bis(trifluoromethylsulfonyl)imide solution. Concentration under reduced pressure yields the ionic liquid.

5-Ethyl-1-(2-ethylhexyl)-4-methyl-1,2,3-triazole (1): brown oil, yield 68\%. ${ }^{1} \mathrm{H}$ NMR $\left(300 \mathrm{MHz}, \mathrm{CDCl}_{3}, \delta / \mathrm{ppm}\right): 0.89(2 \mathrm{t}, 6 \mathrm{H}), 1.14-1.40(\mathrm{~m}+\mathrm{t}, 11 \mathrm{H})$, $1.91(\mathrm{~m}, 1 \mathrm{H}), 2.29(\mathrm{~s}, 3 \mathrm{H}), 2.63\left(\mathrm{q}, 2 \mathrm{H},{ }^{3} \mathrm{~J}=8.0 \mathrm{~Hz}\right), 4.07(\mathrm{~d}, 2 \mathrm{H}) .{ }^{13} \mathrm{C}$ NMR (100 MHz, $\left.\mathrm{CDCl}_{3}, \delta / \mathrm{ppm}\right): 139.97,134.43,51.61,40.07,30.47,28.54$, $23.75,22.93,16.09,14.01,12.29,10.52,10.48$. FT-IR $\left(\mathrm{v} \mathrm{cm}^{-1}\right)$ : 2959, 2931, $2873,2860,1575,1458,1348,1343,1241,1136,1061,1023,966,905$, $810,760,727,615$.

4-Ethyl-5-methyl-1-(2-methylpropyl)-1,2,3-triazole (2): brown oil, yield $61 \%$. ${ }^{1} \mathrm{H}$ NMR $\left(300 \mathrm{MHz}, \mathrm{CDCl}_{3}, \delta / \mathrm{ppm}\right): 0.94\left(\mathrm{~d}, 6 \mathrm{H},{ }^{3} \mathrm{~J}=6.5 \mathrm{~Hz}\right), 1.17(\mathrm{t}$, $\left.3 \mathrm{H},{ }^{3} \mathrm{~J}=8.0 \mathrm{~Hz}\right), 2.29(\mathrm{~s}, 3 \mathrm{H}), 2.63\left(\mathrm{q}, 2 \mathrm{H},{ }^{3} \mathrm{~J}=7.5 \mathrm{~Hz}\right), 3.99\left(\mathrm{~d}, 2 \mathrm{H},{ }^{3} \mathrm{~J}=7.5\right.$ $\mathrm{Hz}) .{ }^{13} \mathrm{C} \mathrm{NMR}\left(100 \mathrm{MHz}, \mathrm{CDCl}_{3}, \delta / \mathrm{ppm}\right): 10.45,13.31,16.03,19.98,29.52$, 
54.99, 134.42, 139.88. FT-IR $\left(\mathrm{v} \mathrm{cm}^{-1}\right): 2969,2959,2929,2887,2875,1573$, 1539, 1465, 1444, 1240, 1216, 1181, 1026, 809.

1-Butyl-5-ethyl-4-methyl-1,2,3-triazole (3): yellow oil, yield 60\%. ${ }^{1} \mathrm{H}$ $\operatorname{NMR}\left(300 \mathrm{MHz}, \mathrm{CDCl}_{3}, \delta / \mathrm{ppm}\right): 0.95$ (t, 3H), 1.18 (t, 3H), 1.38 (6-et, $2 \mathrm{H}$ ), 1.58 (5-et, $2 \mathrm{H}), 2.27$ (s, 3H), 2.65 (q, $2 \mathrm{H}), 4.20$ (t, $2 \mathrm{H}) .{ }^{13} \mathrm{C} \mathrm{NMR}(100 \mathrm{MHz}$, $\left.\mathrm{CDCl}_{3}, \delta / \mathrm{ppm}\right): 10.41,13.37,13.60,15.99,19.89,32.40,47.65,134.13$, 139.93. FT-IR $\left(\mathrm{v} \mathrm{cm}^{-1}\right)$ : 2956, 2929, 2859, 1576, 1457, 1385, 1344, 1252, $1240,1160,1024,966,729$

5-Ethyl-4-methyl-1-hexyl-1,2,3-triazole (4): brown oil, yield $63 \% .{ }^{1} \mathrm{H}$ $\operatorname{NMR}\left(300 \mathrm{MHz}, \mathrm{CDCl}_{3}, \delta / \mathrm{ppm}\right): 0.88(\mathrm{t}, 3 \mathrm{H}), 1.18(\mathrm{t}, 3 \mathrm{H}), 1.32$ (broad m, $6 \mathrm{H}), 1.86$ (5-et, 2H), 2.27 (s, 3H), 2.65 (q, 2H), $4.19(\mathrm{t}, 2 \mathrm{H}) .{ }^{13} \mathrm{C}$ NMR $(100$ $\left.\mathrm{MHz}, \mathrm{CDCl}_{3}, \delta / \mathrm{ppm}\right): 10.42,13.37,13.96,22.47,26.34,30.37,31.30$, 47.94, 134.08, 139.96. FT-IR $\left(\mathrm{v} \mathrm{cm}^{-1}\right)$ : 2955, 2929, 2871, 2859, 1577, 1458 1240, 1196, 1024, 1039.

5-Ethyl-4-methyl-1-(2,2-dimethylpropyl)-1,2,3-triazole (5): orange oil, yield $46 \% .{ }^{1} \mathrm{H}$ NMR (300 MHz, $\left.\mathrm{CDCl}_{3}, \delta / \mathrm{ppm}\right): 1.00(\mathrm{~s}, 9 \mathrm{H}), 1.16(\mathrm{t}, 3 \mathrm{H}$, ${ }^{3} \mathrm{~J}=7.5 \mathrm{~Hz}$ ), $2.29(\mathrm{~s}, 3 \mathrm{H}), 2.66\left(\mathrm{q}, 2 \mathrm{H},{ }^{3} \mathrm{~J}=7.5 \mathrm{~Hz}\right), 3.99(\mathrm{~s}, 2 \mathrm{H}) .{ }^{13} \mathrm{C} \mathrm{NMR}$ $\left(100 \mathrm{MHz}, \mathrm{CDCl}_{3}, \delta / \mathrm{ppm}\right): 10.40,13.09,16.39,27.96,33.34,58.31$, 135.00, 139.44. FT-IR $\left(\mathrm{v} \mathrm{cm}^{-1}\right): 2958,2913,2872,1604,1480,1470,1448$, $1365,1252,1242,1074,1062,1039,911,813,769,698,612$.

1-Cyclohexyl-5-ethyl-4-methyl-1,2,3-triazole (6): yellow oil, yield 52\%. ${ }^{1} \mathrm{H}$ NMR $\left(300 \mathrm{MHz}, \mathrm{CDCl}_{3}, \delta / \mathrm{ppm}\right): 1.16\left(\mathrm{t}, 3 \mathrm{H},{ }^{3} \mathrm{~J}=7.5 \mathrm{~Hz}\right), 1.26-2.16(\mathrm{~m}$, $10 \mathrm{H}), 2.64\left(\mathrm{q}, 2 \mathrm{H},{ }^{3} \mathrm{~J}=7.5 \mathrm{~Hz}\right), 4.03(\mathrm{~m}, 1 \mathrm{H}) .{ }^{13} \mathrm{C} \mathrm{NMR}\left(100 \mathrm{MHz}, \mathrm{CDCl}_{3}\right.$, $\delta / \mathrm{ppm}): 10.29,13.76,15.95,25.16,25.69,33.40,57.72,133.45,139.36$. FT-IR $\left(\mathrm{V} \mathrm{cm}^{-1}\right): 2931,2857,1576,1450,1386,1239,1218,893,825,764$.

1-Benzyl-5-ethyl-4-methyl-1,2,3-triazole (7a) and 1-benzyl-4-ethyl-5methyl-1,2,3-triazole (7b) (10:1): yellow oil, yield $46 \%$. ${ }^{1} \mathrm{H} \mathrm{NMR}(300 \mathrm{MHz}$ $\left.\mathrm{CDCl}_{3}, \delta / \mathrm{ppm}\right): 0.94,1.16\left(\mathrm{t}, 0.3 \mathrm{H},{ }^{3} \mathrm{~J}=7.5 \mathrm{~Hz}\right), 2.06(\mathrm{~s}, 0.3 \mathrm{H}), 2.27(\mathrm{~s}, 3 \mathrm{H})$, $2.52\left(\mathrm{q}, 2 \mathrm{H},{ }^{3} \mathrm{~J}=7.5 \mathrm{~Hz}\right), 2.84\left(\mathrm{q}, 0.2 \mathrm{H},{ }^{3} \mathrm{~J}=7.5 \mathrm{~Hz}\right), 5.45(\mathrm{~s}, 2 \mathrm{H}), 7.1-7.55$ (m, $5 \mathrm{H}) .{ }^{13} \mathrm{C}$ NMR (100 MHz, $\left.\mathrm{CDCl}_{3}, \delta / \mathrm{ppm}\right): 8.29,10.40,12.77,13.18$, $15.99,30.75,51.80,127.02,128.12,128.41,128.85,129.66,134.54$, $135.50,135.98,137.05,138.23,140.69$. FT-IR $\left(\mathrm{v} \mathrm{cm}^{-1}\right): 3063,3032,2972$, 2933, 2875, 1576, 1497, 1455, 1240, 1204, 1156, 1074, 1025, 733.

5-Ethyl-4-methyl-1-(2-methoxyethyl)-1,2,3-triazole (8): yellow oil, yield $61 \%$. ${ }^{1} \mathrm{H} \mathrm{NMR}\left(300 \mathrm{MHz}, \mathrm{CDCl}_{3}, \delta / \mathrm{ppm}\right): 1.17\left(\mathrm{t}, 3 \mathrm{H},{ }^{3} \mathrm{~J}=7.5 \mathrm{~Hz}\right), 2.28(\mathrm{~s}$, $3 \mathrm{H}), 2.69\left(\mathrm{q}, 2 \mathrm{H},{ }^{3} \mathrm{~J}=8.0 \mathrm{~Hz}\right), 3.30(\mathrm{~s}, 3 \mathrm{H}), 3.79\left(\mathrm{t}, 2 \mathrm{H},{ }^{3} \mathrm{~J}=5.5 \mathrm{~Hz}\right), 4.38(\mathrm{t}$, $\left.2 \mathrm{H},{ }^{3} \mathrm{~J}=7.5 \mathrm{~Hz}\right) .{ }^{13} \mathrm{C}$ NMR $\left(100 \mathrm{MHz}, \mathrm{CDCl}_{3}, \delta / \mathrm{ppm}\right): 10.40,13.19,15.87$, $47.81,59.00,71.37,135.40,139.82$. FT-IR $\left(\mathrm{v} \mathrm{cm}^{-1}\right): 2973,2931,2877$, 2833, 2817, 1576, 1454, 1387, 1196, 1117.

4-Ethyl-1-(2-ethylhexyl)-5-propyl-1,2,3-triazole (9): orange oil, yield 49\%. ${ }^{1} \mathrm{H}$ NMR (300 MHz, $\left.\mathrm{CDCl}_{3}, \delta / \mathrm{ppm}\right): 0.84-1.01,1.16-1.40(\mathrm{~m}, 11 \mathrm{H})$, $1.57\left(6\right.$-et, $\left.2 \mathrm{H},{ }^{3} \mathrm{~J}=7.5 \mathrm{~Hz}\right), 1.94(\mathrm{~m}, 1 \mathrm{H}), 2.54-2.70(2 \mathrm{q}, 4 \mathrm{H}),, 4.07(\mathrm{~d}, 2 \mathrm{H}$ $\left.{ }^{3} \mathrm{~J}=7.5 \mathrm{~Hz},\right) .{ }^{13} \mathrm{C}$ NMR $\left(100 \mathrm{MHz}, \mathrm{CDCl}_{3}, \delta / \mathrm{ppm}\right): 10.58,13.68,14.00$, $14.14,18.62$, 22.57, 22.93, 23.89, 24.60, 28.60, 30.56, 40.08, 51.57, $132.50,145.97$. FT-IR $\left(\mathrm{v} \mathrm{cm}^{-1}\right): 2960,2930,2873,2861,1571,1459,1378$, 1191, 1088, 966, 772, 728.

5-Ethyl-1-(2-(1-cyclohexenyl)ethyl)-4-methyl-1,2,3-triazole (10): orange oil, yield $46 \%$. ${ }^{1} \mathrm{H}$ NMR $\left(300 \mathrm{MHz}, \mathrm{CDCl}_{3}, \delta / \mathrm{ppm}\right): 1.18(3 \mathrm{t}, 3 \mathrm{H}$, $\left.{ }^{3} \mathrm{~J}=7.5 \mathrm{~Hz}\right), 1.58(\mathrm{~m}, 4 \mathrm{H}), 1.96(\mathrm{~m}, 4 \mathrm{H}), 2.27(\mathrm{~s}, 3 \mathrm{H}), 2.47(\mathrm{~m}, 2 \mathrm{H}), 2.64(\mathrm{q}$, $2 \mathrm{H}), 4.25\left(\mathrm{~m}, 2 \mathrm{H},{ }^{3} \mathrm{~J}=7.5 \mathrm{~Hz}\right), 5.43(\mathrm{~m}, 1 \mathrm{H}) .{ }^{13} \mathrm{C} \mathrm{NMR}\left(100 \mathrm{MHz}, \mathrm{CDCl}_{3}\right.$, $\delta / \mathrm{ppm}): 10.42,13.38,15.99,22.15,22.78,25.19,28.35,38.82,46.87$, 124.22, 133.52 , 134.12, 139.86. FT-IR $\left(\mathrm{v} \mathrm{cm}^{-1}\right): 2970,2926,2875,2857$, $2835,1576,1668,1447,1437,1386,1343,1240,1198,1112,1025,966$, $919,801$.
1,8-Bis(5-ethyl-4-methyl-1,2,3-triazolyl)octane (11): yellow oil, yield 29\%. ${ }^{1} \mathrm{H}$ NMR (300 MHz, CDCl,$\left.\delta / p p m\right): 1.18$ (t, $\left.6 \mathrm{H},{ }^{3} \mathrm{~J}=7.5 \mathrm{~Hz}\right), 1.33$ (broad m, 8H), 1.85 (broad 5-et, 4H), $2.27(\mathrm{~s}, 6 \mathrm{H}), 2.64\left(\mathrm{q}, 4 \mathrm{H},{ }^{3} \mathrm{~J}=7.5 \mathrm{~Hz}\right.$ ), $4.18\left(\mathrm{t}, 4 \mathrm{H},{ }^{3} \mathrm{~J}=7.0 \mathrm{~Hz}\right) .{ }^{13} \mathrm{C} \mathrm{NMR}\left(100 \mathrm{MHz}, \mathrm{CDCl}_{3}, \delta / \mathrm{ppm}\right): 10.40,23.36$, $15.97,26.47,28.85,30.27,47.82,134.09,140.00$. FT-IR $\left(\mathrm{v} \mathrm{cm}^{-1}\right): 2971$, 2929, 2857, 1576, 1458, 1386, 1344, 1193, 1024

\section{4-Ethyl-1,3-bis(2-ethylhexyl)-5-methyl-1,2,3-triazolium}

bis(trifluoromethylsulfonyl)imide [EhEhT][Tf $\left.{ }_{2} \mathrm{~N}\right]$ : brown oil, yield $67 \%$. ${ }^{1} \mathrm{H} \mathrm{NMR}\left(300 \mathrm{MHz}, \mathrm{CDCl}_{3}, \mathrm{\delta} / \mathrm{ppm}\right)$ : 0.86-0.96 (m, 12H, 1.18-1.42 (m, 19H), $1.96(\mathrm{~m}, 2 \mathrm{H}), 2.46(\mathrm{~s}, 3 \mathrm{H}), 2.85\left(\mathrm{q}, 2 \mathrm{H},{ }^{3} \mathrm{~J}=7.5 \mathrm{~Hz}\right), 4.30\left(2 \mathrm{~d}, 4 \mathrm{H},{ }^{3} \mathrm{~J}=7.0\right.$ $\mathrm{Hz}) .{ }^{13} \mathrm{C} \mathrm{NMR}\left(100 \mathrm{MHz}, \mathrm{CDCl}_{3}, \delta / \mathrm{ppm}\right): 8.61,10.10,12.67,13.89,16.57$, $22.78,23.38,28.20,30.10,39.08,39.38,54.45,119.73\left(\mathrm{q},{ }^{1} \mathrm{~J}=320 \mathrm{~Hz}\right)$, 137.22, 142.03 . FT-IR $\left(\mathrm{v} \mathrm{cm}^{-1}\right)$ : 2962, 2934, 2875, 2864, 1597, 1462, 1383, $1350,1225,1181,1136,1055,616570,512 . \mathrm{CHN}$ calculated for $\mathrm{C}_{23} \mathrm{H}_{42} \mathrm{~F}_{6} \mathrm{~N}_{4} \mathrm{O}_{4} \mathrm{~S}_{2}$ : C 44.79\%, H 6.86\%, N 9.08\%; found: C $45.23 \%, \mathrm{H}$ $6.84 \%$, N $8.82 \%$.

4-Ethyl-5-methyl-1,3-bis(2-methylpropyl)-1,2,3-triazolium bis(trifluoromethylsulfonyl)imide ['Bu'BuT] $\left[\mathrm{Tf}_{2} \mathbf{N}\right]$ : brown oil, yield $35 \%$. ${ }^{1} \mathrm{H} \mathrm{NMR}\left(300 \mathrm{MHz}, \mathrm{CDCl}_{3}, \delta / \mathrm{ppm}\right): 0.99+1.00\left(2 \mathrm{~d}, 12 \mathrm{H},{ }^{3} \mathrm{~J}=6.5 \mathrm{~Hz}\right), 1.27$ (t, $\left.3 \mathrm{H},{ }^{3} \mathrm{~J}=7.5 \mathrm{~Hz}\right), 2.29(\mathrm{~m}, 2 \mathrm{H}), 2.46(\mathrm{~s}, 3 \mathrm{H}), 2.85\left(\mathrm{q}, 2 \mathrm{H},{ }^{3} \mathrm{~J}=7.5 \mathrm{~Hz}\right)$, 4.25/4.22 (2d, 4H, $\left.{ }^{3} \mathrm{~J}=7.5 \mathrm{~Hz}\right) .{ }^{13} \mathrm{C}$ NMR $\left(100 \mathrm{MHz}, \mathrm{CDCl}_{3}, \delta / \mathrm{ppm}\right): 8.55$, 12.22, 16.50, 19.56, 28.55, 28.82, 57.80, 57.92, 39.38, 54.45, 119.73 ( $\left.\mathrm{q},{ }^{1} \mathrm{~J}=-320 \mathrm{~Hz}\right), 137.22,142.03 . \mathrm{FT}-\mathrm{IR}\left(\mathrm{v} \mathrm{cm}^{-1}\right): 2969,2939,2880,2850$, $1597,1470,1347,1180,1134,1055,613,570,511 . \mathrm{CHN}$ calculated for $\mathrm{C}_{15} \mathrm{H}_{26} \mathrm{~F}_{6} \mathrm{~N}_{4} \mathrm{O}_{4} \mathrm{~S}_{2}$ : C $35.71 \%$, H 5.19\%, N $11.11 \%$; found: C $35.84 \%, \mathrm{H}$ $4.85 \%$, N $9.21 \%$.

4-Ethyl-1-(2-ethylhexyl)-5-methyl-3-methylethyl-1,2,3-triazolium bis(trifluoromethylsulfonyl)imide [Eh'PrT] $\left[\mathrm{Tf}_{2} \mathrm{~N}\right]$ : brown oil, yield $88 \%$ ${ }^{1} \mathrm{H}$ NMR $\left(300 \mathrm{MHz}, \mathrm{CDCl}_{3}, \delta / \mathrm{ppm}\right): 0.91(\mathrm{~m}, 6 \mathrm{H}), 1.30(\mathrm{~m}, 11 \mathrm{H}), 1.62(\mathrm{~d}$ $\left.6 \mathrm{H},{ }^{3} \mathrm{~J}=6.5 \mathrm{~Hz}\right), 1.97(\mathrm{~m}, 1 \mathrm{H}), 2.49(\mathrm{~s}, 3 \mathrm{H}), 2.85\left(\mathrm{q}, 2 \mathrm{H},{ }^{3} \mathrm{~J}=6.5 \mathrm{~Hz},{ }^{3} \mathrm{~J}=8.0\right.$ $\mathrm{Hz}), 4.30$ (d, 2H), 4.88 (7-et, $1 \mathrm{H}) .{ }^{13} \mathrm{C} \mathrm{NMR}\left(100 \mathrm{MHz}, \mathrm{CDCl}_{3}, \delta / \mathrm{ppm}\right): 8.34$, $10.17,12.25,13.88,16.47,21.65,22.76,23.49,28.11,30.13,39.31,54.54$, $54.99,119.78\left(\mathrm{q},{ }^{1} \mathrm{~J}=-320 \mathrm{~Hz}\right), 136.25,141.87$. FT-IR $\left(\mathrm{v} \mathrm{cm}^{-1}\right): 2962,2920$, 2876, 2850, 1599, 1462, 1349, 1179, 1134, 1055, 614, 570, 511. CHN calculated for $\mathrm{C}_{18} \mathrm{H}_{32} \mathrm{~F}_{6} \mathrm{~N}_{4} \mathrm{O}_{4} \mathrm{~S}_{2}$ : C $39.55 \%, \mathrm{H} 5.90 \%, \mathrm{~N} 10.25 \%$; found: C $40.03 \%$, H $6.05 \%$, N $9.21 \%$.

\section{4-Ethyl-5-methyl-1,3-dihexyl-1,2,3-triazolium}

bis(trifluoromethylsulfonyl)imide [HHT] $\left[\mathrm{Tf}_{2} \mathrm{~N}\right]$ : brown oil, yield $64 \%$. ${ }^{1} \mathrm{H}$ $\operatorname{NMR}\left(300 \mathrm{MHz}, \mathrm{CDCl}_{3}, \delta / \mathrm{ppm}\right): 0.90\left(\mathrm{t}, 6 \mathrm{H},{ }^{3} \mathrm{~J}=7.0 \mathrm{~Hz}\right), 1.22-1.34(\mathrm{~m}, 15 \mathrm{H})$, $1.95\left(6\right.$-et, $\left.4 \mathrm{H},{ }^{3} \mathrm{~J}=7.0 \mathrm{~Hz}\right), 2.46(\mathrm{~s}, 3 \mathrm{H}), 2.85\left(\mathrm{q}, 2 \mathrm{H},{ }^{3} \mathrm{~J}=8.0 \mathrm{~Hz}\right), 4.38(2 \mathrm{t}$, $4 \mathrm{H}) .{ }^{13} \mathrm{C} \mathrm{NMR}\left(100 \mathrm{MHz}, \mathrm{CDCl}_{3}, \delta / \mathrm{ppm}\right): 8.42,12.23,14.00,14.14,16.46$, 22.31, 25.92, 25.96, 28.30, 28.83, 33.93, 30.96, 51.12, 51.25, 119.81 (q, $\left.{ }^{1} \mathrm{~J}=-320 \mathrm{~Hz}\right), 136.72,141.72 . \mathrm{FTIR}\left(\mathrm{v} / \mathrm{cm}^{-1}\right): 2958,2933,2862,1599,1461$, $1349,1135,1179,1054,615,570,512 . \mathrm{CHN}$ calculated for $\mathrm{C}_{19} \mathrm{H}_{34} \mathrm{~F}_{6} \mathrm{~N}_{4} \mathrm{O}_{4} \mathrm{~S}_{2}$ : C $40.71 \%, \mathrm{H} 6.11 \%, \mathrm{~N}$ 9.99\%; found: C $41.48 \%, \mathrm{H}$ $6.26 \%, N 10.71 \%$.

4-Ethyl-5-methyl-1,3-dihexyl-1,2,3-triazolium nitrate [EhEhT] $\left[\mathrm{NO}_{3}\right]$ brown oil, total isolated yield $57 \%$ with respect to azide. ${ }^{1} \mathrm{H} \mathrm{NMR}(300 \mathrm{MHz}$, $\mathrm{CDCl} 3, \delta / \mathrm{ppm}): 0.91(2 \mathrm{t}, 12 \mathrm{H}), 1.31(\mathrm{~m}, 19 \mathrm{H}), 1.98(\mathrm{~m}, 2 \mathrm{H}), 2.54(\mathrm{~s}, 3 \mathrm{H})$, 2.91 (q, 2H), 4.38 (d, 4H). ${ }^{13} \mathrm{C} \mathrm{NMR}(100 \mathrm{MHz}, \mathrm{CDCl} 3, \delta / \mathrm{ppm}): 142.05$ $137.42,54.44,39.40,39.12,30.15,28.26,23.44,22.82,16.66,13.94$ 12.38, 10.22, 8.80. FTIR(v/cm $\left.{ }^{-1}\right): 2959,2931,2873,2861,1596,1460$ $1328,1181,1109,1096,1038,971,586,829,771,728 .[2,3] \mathrm{CHN}$ calculated for $\mathrm{C}_{21} \mathrm{H}_{42} \mathrm{~N}_{4} \mathrm{O}_{3} \cdot \mathrm{H}_{2} \mathrm{O}$ : \% $60.54, \% \mathrm{H} 10.65$, \%N 13.45, found \%C $60.87, \% \mathrm{H} 10.41, \% \mathrm{~N} 12.93$. 


\section{Acknowledgements}

The authors wish to thank FWO Flanders for funding (PhD fellowship to SR). Dirk Henot and Karel Duerinckx are acknowledged for $\mathrm{CHN}$ and NMR measurements, respectively.

Keywords: ionic liquids • green chemistry • Grignard reaction • triazolium salts

[1] M. Hayyan, F. S. Mjalli, M. A. Hashim, I. M. AINashef, T. X. Mei, J. of Ind. Eng. Chem. 2013, 19, 106-112.

[2] Q. Zhang, Q. Wang, S. Zhang, X. Lu, X. Zhang, ChemPhysChem 2016, 17, 335-351.

[3] S. Sowmiah, V. Srinivasadesikan, M.-C. Tseng, Y.-H. Chu, Molecules 2009, 14, 3780-3813.

[4] D. Landini, A. Maia, A. Rampoldi, J. Org. Chem. 1986, 51, 3187-3191.

[5] K. C. Lethesh, W. Dehaen, K. Binnemans, RSC Adv. 2013, 4, 4472-4477.

[6] B. Siegel, J. Am. Chem. Soc. 1979, 101, 2265-2268.

[7] A. A. M. Lapis, L. F. de Oliveira, B. A. D. Neto, J. Dupont, ChemSusChem 2008, 1, 759-762.

[8] K. M. Hugar, H. A. Kostalik, G. W. Coates, J. Am. Chem. Soc. 2015, 137, 8730-8737.

[9] C. Maton, N. De Vos, B. I. Roman, E. Vanecht, N. R. Brooks, K. Binnemans, S. Schaltin, J. Fransaer, C. V. Stevens, Chemphyschem 2012, 13, 3146-3157.

[10] V. Jurčík, R. Wilhelm, Green Chem. 2005, 7, 844-848.

[11] L. Myles, R. G. Gore, N. Gathergood, S. J. Connon, Green Chem. 2013, 15, 2740-2746.

[12] B. Lin, H. Dong, Y. Li, Z. Si, F. Gu, F. Yan, Chem. Mater. 2013, 25, 18581867.

[13] C. Deferm, M. Van de Voorde, J. Luyten, H. Oosterhof, J. Fransaer, K. Binnemans, Green Chem. 2016, 18, 4116-4127.

[14] K. Larsson, K. Binnemans, Hydrometallurgy 2015, 156, 206-214.

[15] K. Paduszyński, U. Domańska, J. Chem. Inf. Model. 2014, 54, 1311 1324.

[16] D. Depuydt, A. Van den Bossche, W. Dehaen, K. Binnemans, Chem. Commun. 2017, 53, 5271-5274.

[17] T. Vander Hoogerstraete, K. Binnemans, Green Chem. 2014, 16, 1594 1606.

[18] M.-C. Tseng, H.-C. Kan, Y.-H. Chu, Tetrahedron Lett. 2007, 48, 90859089.

[19] S. Sanghi, E. Willett, C. Versek, M. Tuominen, E. Bryan Coughlin, RSC Adv. 2012, 2, 848-853.

[20] M.-C. Tseng, H.-T. Cheng, M.-J. Shen, Y.-H. Chu, Org. Lett. 2011, 13, 4434-4437.

[21] S. Raiguel, D. Depuydt, T. Vander Hoogerstraete, J. Thomas, W. Dehaen, K. Binnemans, Dalton Trans. 2017, 46, 5269-5278.

[22] S. Hanelt, J. Liebscher, Synlett 2008, 2008, 1058-1060.

[23] J. M. Aizpurua, R. M. Fratila, Z. Monasterio, N. Pérez-Esnaola, E. Andreieff, A. Irastorza, M. Sagartzazu-Aizpurua, New J. Chem. 2014, 38, 474-480.
[24] J. T. Fletcher, M. E. Keeney, S. E. Walz, Synthesis 2010, 2010, 33393345 .

[25] Z. Yakob, J. Liebscher, in Ionic Liquids - Classes and Properties, Intech Open, London, 2011, pp. 3-22.

[26] S. S. Khan, S. Hanelt, J. Liebscher, Arkivoc 2009, xii.

[27] G. P. S. Lau, J.-D. Décoppet, T. Moehl, S. M. Zakeeruddin, M. Grätzel, P. J. Dyson, Sci. Rep. 2015, 5, 18158.

[28] G. P. S. Lau, H. N. Tsao, S. M. Zakeeruddin, M. Grätzel, P. J. Dyson, ACS Appl. Mater. Interfaces 2014, 6, 13571-13577.

[29] K. Stappert, D. Ünal, B. Mallick, A.-V. Mudring, J. Mater. Chem. C 2014 2, 7976-7986.

[30] J. Shah, S. S. Khan, H. Blumenthal, J. Liebscher, Synthesis 2009, 2009, 3975-3982.

[31] Z. Yacob, J. Shah, J. Leistner, J. Liebscher, Synlett 2008, 2008, 23422344.

[23] M. Lartey, J. Meyer-llse, J. D. Watkins, E. A. Roth, S. Bowser, V. A. Kusuma, K. Damodaran, X. Zhou, M. Haranczyk, E. Albenze, et al., PCCP 2015, 17, 29834-29843.

[33] A. Massarotti, S. Aprile, V. Mercalli, E. Del Grosso, G. Grosa, G. Sorba, G. C. Tron, ChemMedChem n.d., 9, 2497-2508.

[34] D. Dheer, V. Singh, R. Shankar, Bioorg. Chem. 2017, 71, 30-54.

[35] B. Schulze, U. S. Schubert, Chem. Soc. Rev. 2014, 43, 2522-2571.

[36] M. Zurro, O. G. Mancheño, Chem. Rec. 2016, 17, 485-498.

[37] J. Huo, H. Hu, M. Zhang, X. Hu, M. Chen, D. Chen, J. Liu, G. Xiao, Y. Wang, Z. Wen, RSC Advances 2017, 7, 2281-2287.

[38] I. Bratko, G. Guisado-Barrios, I. Favier, S. Mallet-Ladeira, E. Teuma, E. Peris, M. Gómez, Eur. J. Org. Chem. 2014, 10, 2160-2167.

[39] V. V. Rostovtsev, L. G. Green, V. V. Fokin, K. B. Sharpless, Angew. Chem. Int. Ed. 2002, 114, 2708-2711.

[40] L. Zhang, X. Chen, P. Xue, H. H. Y. Sun, I. D. Williams, K. B. Sharpless, V. V. Fokin, G. Jia, J. Am. Chem. Soc. 2005, 127, 15998-15999.

[41] M. M. Majireck, S. M. Weinreb, J. Org. Chem. 2006, 71, 8680-8683.

[42] J. Thomas, S. Jana, J. John, S. Liekens, W. Dehaen, Chem. Commun. 2016, 52, 2885-2888.

[43] V. A. Bakulev, T. Beryozkina, J. Thomas, W. Dehaen, Eur. J. Org Chem. 2018, 3, 262-294.

[44] D. Prat, J. Hayler, A. Wells, Green Chem. 2014, 16, 4546-4551.

[45] S. Zhang, N. Sun, X. He, X. Lu, X. Zhang, J. Phys. Chem. Ref. Data 2006 , 35, 1475-1517.

[46] K.-M. Liu, F. Zhang, X.-F. Duan, Eur. J. Org. Chem. 2013, 23, 61526157.

[47] M. C. Law, K.-Y. Wong, T. H. Chan, Chem. Commun. 2006, 27, 24572459.

[48] T. Itoh, K. Kude, S. Hayase, M. Kawatsura, Tetrahedron Lett. 2007, 48, 7774-7777.

[49] S. T. Handy, J. Org. Chem. 2006, 71, 4659-4662.

[50] Science of Synthesis: Houben-Weyl Methods of Molecular Transformations Vol. 33: Ene- $X$ Compounds ( $X=S$, Se, Te, N, P), Georg Thieme Verlag, 2014.

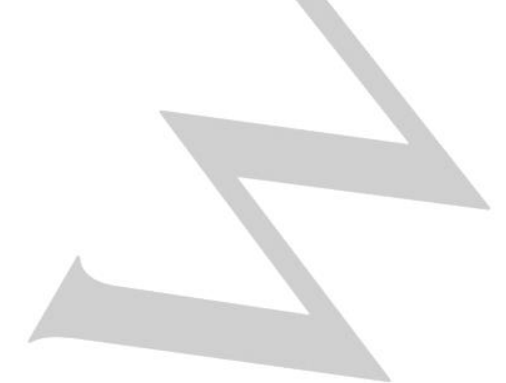


Entry for the Table of Contents (Please choose one layout)

Layout 1:

\section{FULL PAPER}

A new, upscalable method for the synthesis of 1,2,3-triazolium ionic liquids is described for scales up to $40+$ grams. The influence of various substituents on the stability of these structures towards bases is investigated. One example was found to exhibit noteworthy stability towards $\mathrm{NaOH}$ and Grignard reagents.

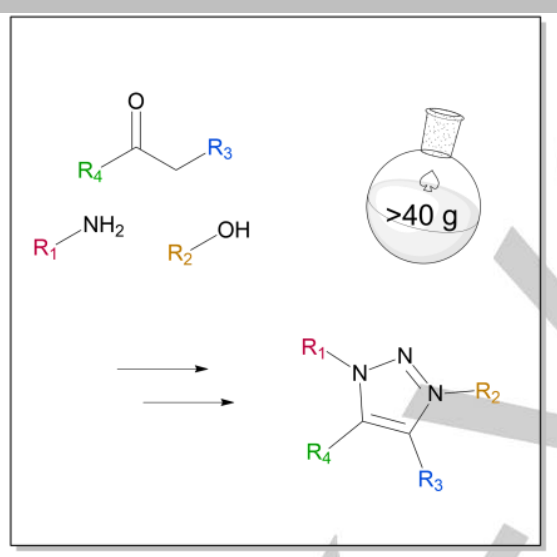

\section{Triazolium ionic liquids}

Stijn Raiguel, Joice Thomas, Koen Binnemans, Wim Dehaen*

Page No. - Page No.

Multi-gram scalesynthesis of $1,2,3-$ triazolium ionic liquids and assay of their resistance towards bases

*one or two words that highlight the emphasis of the paper or the field of the study

\section{Layout 2:}

\section{FULL PAPER}

((Insert TOC Graphic here; max. width: $11.5 \mathrm{~cm}$; max. height: $2.5 \mathrm{~cm}$; NOTE: the final letter height should not be less than $2 \mathrm{~mm}$.))

Text for Table of Contents

\section{Key Topic*}

Author(s), Corresponding Author(s)*

Page No. - Page No.

Title

*one or two words that highlight the emphasis of the paper or the field of the study 